\title{
Response of heterotrophic stream biofilm communities to a gradient of resources
}

\author{
D. J. Van Horn ${ }^{1, *}$, R. L. Sinsabaugh ${ }^{1}$, C. D. Takacs-Vesbach ${ }^{1}$, K. R. Mitchell ${ }^{1,2}$, \\ C. N. Dahm ${ }^{1}$ \\ ${ }^{1}$ Department of Biology, University of New Mexico, Albuquerque, New Mexico 87131, USA \\ ${ }^{2}$ Present address: Department of Microbiology \& Immunology, University of British Columbia Life Sciences Centre, \\ Vancouver BC V6T 1Z3, Canada
}

\begin{abstract}
The metabolism and biogeochemical cycles of aquatic ecosystems are largely mediated by microbial communities, with biofilm assemblages dominating in stream ecosystems. To determine the effects of the availability of resources on the structure and function of heterotrophic stream biofilms, we created an enrichment gradient by amending darkened stream channel mesocosms with a stoichiometrically balanced solution of sucrose, $\mathrm{NO}_{3}{ }^{-}$and $\mathrm{PO}_{4}{ }^{3-}$. A total of 1902 bacterial partial 16S rRNA gene sequences yielded 293 unique operational taxonomic units (OTUs, $97 \%$ sequence similarity). Significant differences $(p<0.005)$ were detected between communities from all treatments with the exception of the 2 highest enrichment levels, with increasing enrichment resulting in progressive community divergence and declining diversity. Both the productivity and function of the biofilm community increased exponentially with enrichment, with exponents of 1.5 for areal mass, 2.3 for live-cell density, and 2.5 to 3.5 for the activities of 5 extracellular enzymes. The nonlinear increase in functional capacity suggests that heterotrophic biofilms are highly responsive to the availability of resources, probably as a result of the physical structures and synergistic social interactions found in biofilm assemblages.
\end{abstract}

KEY WORDS: Heterotrophic stream biofilm $\cdot$ Resource gradient $\cdot$ Extracellular enzymes $\cdot 16 \mathrm{~S}$ rRNA gene sequences

Resale or republication not permitted without written consent of the publisher

\section{INTRODUCTION}

The metabolism and biogeochemical cycles of aquatic ecosystems are largely mediated by microbial communities. Aquatic microbial communities occur in 2 primary forms: (1) planktonic assemblages that develop in the water columns of marine, lentic and large river environments, and (2) attached biofilm communities whose contributions to metabolism in the ecosystem are most prominent in small to mid-sized streams, wetlands and shallow lakes. While plankton and biofilm communities share similar biogeochemical and organic carbon processing functions, they have markedly different physical structures and biotic interactions that may lead to differing responses to changes in the supply of resources.

Planktonic microbial communities lack self-imposed physical structure. Metabolism is regulated by topdown (predator-prey) and bottom-up (resource avail- ability) interactions. Bottom-up effects are dominant in oligotrophic systems and top-down interactions are most important in eutrophic environments (Dufour \& Torreton 1996, Gasol et al. 2002, Vargas et al. 2007, Thelaus et al. 2008). Within planktonic communities there is little evidence for cooperative or synergistic interactions among populations. Predator-prey interactions create a microbial loop that either packages carbon and nutrients for higher trophic levels or returns dissolved carbon and nutrients to support bacterial production.

In contrast to planktonic microbial communities, attached microbial populations form complex structured associations in biofilms. When planktonic microbial cells adhere to solid surfaces, signal cascades alter gene expression and initiate the formation of a dense layer of extracellular polymeric substances (Watnick \& Kolter 2000, Beloin \& Ghigo 2005) that shield biofilm organisms from predators and insulate 
inhabitants from external variables such as $\mathrm{pH}$, temperature, ultraviolet light, desiccation, and toxic or antimicrobial substances (Webb et al. 2003, HallStoodley et al. 2004). As biofilms thicken, physical and chemical gradients form internally, promoting cooperative metabolic interaction within and between populations (Costerton et al. 1995, Davey \& O'Toole 2000). Populations interact through multiple intercellular communication mechanisms, including quorum sensing (Hense et al. 2007), programmed cell death within populations (Webb et al. 2003), and lateral gene transfer within and among species (Watnick \& Kolter 2000, Parsek \& Fuqua 2004).

The substantial differences between planktonic and biofilm associations may influence the response of these communities to an altered supply of resources. Because they are simpler to manipulate, plankton communities have been the focus of most studies that examine the composition and metabolism of microbial communities in relation to the availability of resources. Meta-analyses of cross-site eutrophication gradients show that planktonic primary production increases linearly with nutrient enrichment, stimulating a linear, but less than 1:1, increase in bacterioplankton production (Cole et al. 1988, Thelaus et al. 2008). Bacterial biomass, however, increases more slowly than production as a result of increased predation (Thelaus et al. 2008). Similar patterns have been observed using experimental mesocosms through the manipulation of primary production (Hobbie \& Cole 1984, Oviatt et al. 1986) and direct additions of $\mathrm{C}, \mathrm{N}$ and $\mathrm{P}$ (Joint et al. 2002, Smith \& Prairie 2004, Jansson et al. 2006).

In contrast, studies on the effects of the supply of resources on the structure and function of biofilm communities are limited. Nutrient or carbon enrichment from either anthropogenic sources (Brümmer et al. 2003, Kobayashi et al. 2009) or experimental manipulations (Olapade \& Leff 2005, 2006) have been shown to alter the composition of the biofilm community and the abundance of bacteria from different phyla, sub-phyla, genera and species. Experimental manipulations show that the greatest changes occur in response to additions of labile carbon, while the addition of complex carbon stimulates or suppresses various members of the microbial community (Olapade \& Leff 2005, 2006). A whole-stream addition of nitrogen and phosphorus significantly affected microbial function (Stelzer et al. 2003). Respiration rates increased for a variety of carbon substrates, with the greater increases associated with low-nutrient substrates. Several experimental single-level enrichments in microcosms suggest that the simultaneous addition of $\mathrm{C}, \mathrm{N}$ and $\mathrm{P}$ alters community composition (Ylla et al. 2009) and-even at low levels-leads to substantial, and possibly non-linear, changes in biofilm production and function (Mohamed et al. 1998, Chenier et al. 2003, 2006). While the studies mentioned above have investigated the effects of adding carbon or nutrients, or single-level carbon and nutrients, on various aspects of stream biofilms, to our knowledge no study has investigated the effects of an enrichment gradient on the structure and function of a biofilm community.

In this study, we used stream mesocosms to measure the effects of a gradient of resources - that included carbon, nitrogen and phosphorus - on heterotrophic biofilm productivity, potential extracellular enzyme activity (EEA), and community diversity and structure. We compared the magnitude and linearity of these responses in relation to the supply of resources, and contrasted these responses to those reported for planktonic microbial communities.

\section{MATERIALS AND METHODS}

General experimental design. Heterotrophic microbial biofilms were established in complete darkness in 15 experimental stream channel mesocosms (Singer et al. 2006). The channels (depth/width/length: 0.02/ 0.1/3.0 m) were lined with removable unglazed ceramic tiles, supplied with stream water to ensure colonization by ambient microbial populations, and continually enriched with a stoichiometrically balanced (C:N:P ratio 106:16:1) solution of dissolved organic carbon (DOC) in the form of sucrose, $\mathrm{NO}_{3}{ }^{-}\left(\mathrm{NaNO}_{3}\right)$, and $\mathrm{PO}_{4}{ }^{3-}\left(\mathrm{KH}_{2} \mathrm{PO}_{4}\right)$ (Fig. 1). Labile substrates were chosen to ensure that a productivity gradient was established. Water was diverted into the mesocosms from an intermittent stream located in Bear Canyon in the foothills of the Sandia Mountains near Albuquerque, New Mexico. The stream water was filtered (10 $\mu \mathrm{m}$ filter) prior to delivery to a header tank that distributed water at a rate of $0.031 \mathrm{~s}^{-1}$ per mesocosm, generating a nominal flow velocity of $\sim 2 \mathrm{~cm} \mathrm{~s}^{-1}$ within the channels. Enrichment treatments were multiples of the ambient DOC concentration $\left(\sim 1.5 \mathrm{mg} \mathrm{l}^{-1}\right)$. Treatments included no enrichment in control channels, and $2 \times, 4 \times, 8 \times$ and $10 \times$ increases in ambient DOC concentration with supplemental $\mathrm{N}\left(\mathrm{NO}_{3}{ }^{-}\right.$, ambient concentration $=0.002 \mathrm{mg}$ $\left.\mathrm{l}^{-1} \mathrm{NO}_{3}{ }^{-}-\mathrm{N}\right)$ and $\mathrm{P}\left(\mathrm{PO}_{4}{ }^{3-}\right.$, ambient concentration = $0.002 \mathrm{mg} \mathrm{l}^{-1} \mathrm{PO}_{4}{ }^{3-}$ ) added to preserve a C:N:P ratio of 106:16:1. Nutrient solutions were metered into channels behind baffles to ensure even mixing. Three replicate channels were used for each level of enrichment. After 3 wk of growth, from May 8 to May 28, 2008the time necessary to produce a mature biofilm - colonized tiles were collected for biofilm analyses. Three replicate tiles were collected for analysis for each biofilm production/function measurement from the same location in each channel to facilitate between- 


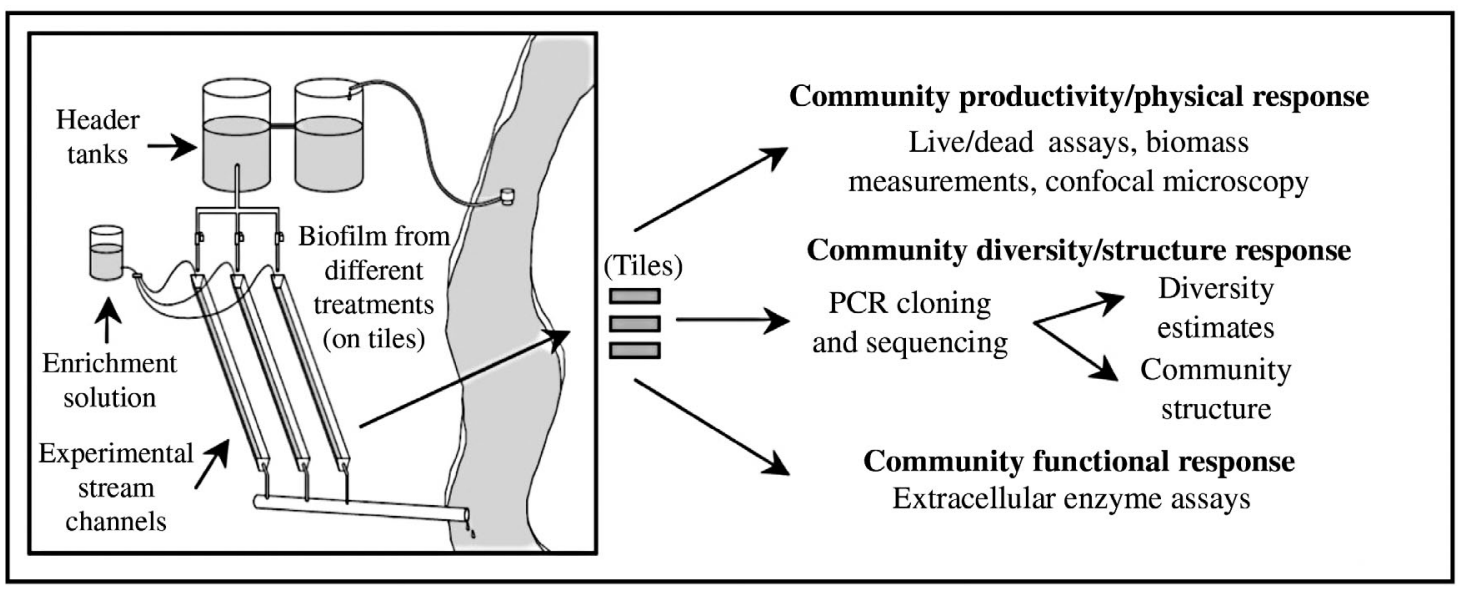

Fig. 1. Schematic experimental design for the stream-side mesocosm experiment

channel comparisons. A single tile was analyzed from each channel for 16S rRNA gene sequences.

Biofilm productivity and physical structure. Biofilm mass (dry mass, DM), and ash-free dry mass, AFDM) was measured by scraping tiles with a metal spatula and depositing biofilm material onto ashed, weighed glass-fiber filters placed in aluminum pans. Filters were dried at $80^{\circ} \mathrm{C}$, reweighed to calculate DM, and ashed at $500^{\circ} \mathrm{C}$ for $3 \mathrm{~h}$. Ashed filters were reweighed and AFDM was calculated as the difference between dry mass and ash mass.

The relative abundance of live and dead cell biomass was assessed using a BacLight ${ }^{\mathrm{TM}}$ kit (Invitrogen). The stains were checked for linearity of fluorescence over the biofilm cell densities to be analyzed using serial dilutions of a high-biomass sample. Sample blanks were also performed using $50 \mathrm{mM}$ bicarbonate buffer. Samples were homogenized in a $50 \mathrm{mM}$ bicarbonate buffer (pH 8), eight $250 \mu$ replicates for each sample were pipetted into black 96-well microplates, and $6 \mu \mathrm{l}$ of an equal mixture of a 1:10 dilution of the stains were added to the microplate wells. Samples were incubated at room temperature in the dark for $\sim 15 \mathrm{~min}$ and then read on an fmax Fluorescence Microplate Reader (Molecular Devices) set to an excitation wavelength of $485 \mathrm{~nm}$ and an emission wavelength of $538 \mathrm{~nm}$ for the $\mathrm{SYTO}^{\circledR} 9$ stain, and an excitation wavelength of $485 \mathrm{~nm}$ and an emission wavelength of $591 \mathrm{~nm}$ for the propidium iodide stain. Results were normalized by the area of the tile sampled and were corrected for dilution where appropriate. The microplate method described above has been validated for measuring live and dead cell abundance in single-species cultures (Alakomi et al. 2005). However, when used in a complex community, or to compare communities dominated by organisms with different cell morphologies, as in the present study, the values of fluorescence represent the relative abundance of live and dead cell biomass rather than the absolute abundance of cells.

The physical structure of biofilms was assessed using confocal microscopy. Briefly, a single biofilm-colonized tile from each channel was placed in a plastic tray while still submerged in the experimental stream channel, and transported on ice to the Keck Confocal Laboratory at the University of New Mexico. Samples were stained with the live/dead stain described above and imaged using a $5 \times$ objective on a LSM 510 confocal microscope (Carl Zeiss).

Biofilm function. Biofilm function was assessed by measuring the potential activity of 5 hydrolytic extracellular enzymes: $\alpha$-glucosidase (AG), $\beta$-glucosidase (BG), $N$-acetylglucosaminidase (NAG), alkaline phosphatase (AP) and leucine aminopeptidase (LAP). Potential activities were measured using methylumbelliferyl-linked substrates following protocols similar to those described by Sinsabaugh et al. (1997). Biofilm was homogenized in $50 \mathrm{mM}$ bicarbonate buffer ( $\mathrm{pH} 8)$. Aliquots (each $200 \mu \mathrm{l}$ ) of biofilm homogenate and $50 \mu \mathrm{l}$ of $200 \mu \mathrm{M}$ substrate were added to black, 96-well microplates with 16 replicate wells per sample. The microplates were incubated in the dark at room temperature. Each plate contained reference standards, substrate controls, and sample controls. Fluorescence was measured periodically for up to $19 \mathrm{~h}$ using an fmax Fluorescence Microplate Reader set to an excitation wavelength of $365 \mathrm{~nm}$ and an emission wavelength of $450 \mathrm{~nm}$. The fluorescence results were checked for linearity over the incubation period, and activities were calculated as nmol substrate converted per hour for each $\mathrm{cm}^{2}$ of tile $\left(\mathrm{nmol} \mathrm{h} \mathrm{h}^{-1} \mathrm{~cm}^{-2}\right)$.

Biofilm community structure and diversity. Samples for analysis of the 16S rRNA gene sequence were 
stored in sucrose lysis buffer (SLB) at $-80^{\circ} \mathrm{C}$ until extraction with the cetyltrimethylammonium bromide (CTAB) method as described by Mitchell \& TakacsVesbach (2008). Bacterial 16S rRNA gene sequences were amplified using the bacteria-specific forward primer 8F 5'-AGA GTT TGA TCC TGG CTC AG-3' and the reverse primer 1492R 5'-GTT TAC CTT GTT ACG ACT T-3' (Lane 1991) in triplicate $50 \mu$ reactions containing $5 \mu \mathrm{l} \mathrm{10 \times}$ buffer (Promega Buffer B with $1.5 \mathrm{mM} \mathrm{MgCl}$ ), $12.5 \mathrm{mM}$ each dNTP (BioLine USA), $20 \mathrm{pmol}$ each of $8 \mathrm{~F}$ and 1492R primers, and $2.5 \mathrm{U}$ Taq polymerase (Promega). The PCR thermal cycling profile was 10 min at $94^{\circ} \mathrm{C}_{i} 30$ cycles of $30 \mathrm{~s}$ at $94^{\circ} \mathrm{C}, 30 \mathrm{~s}$ at $50^{\circ} \mathrm{C}, 90 \mathrm{~s}$ at $72^{\circ} \mathrm{C}_{i} 7 \mathrm{~min}$ at $72^{\circ} \mathrm{C}$ (ABI GeneAmp 2700, Applied Biosystems). Triplicate 16S rRNA gene amplifications were pooled and gel-purified using a DNA Purification Kit (MoBio Laboratories), and cloned using a TOPO TA Cloning Kit (Invitrogen). For each library, 192 clones were sequenced using high-throughput Sanger sequencing (ABI 3730 Capillary Sequencer, Applied Biosystems), half with vector specific primers (M13) and half with 8F primers. Sequences were deposited in GenBank under the accession numbers JF695046 to JF696947.

Data analysis. Differences among enrichment treatments for biomass, enzyme activities, and live/dead cell biomass were assessed using 1-way analysis of variance (1-way ANOVA) and Bonferroni multiple comparisons on log-transformed data using SAS ${ }^{\circledR}$ software (Version 9.2, Copyright SAS Institute). Standardized Major Axis Tests \& Routines (SMATR; Falster et al. 2006, Warton et al. 2006) was used to calculate scaling exponents (b) and 95\% confidence intervals (CI) for biomass, enzyme activities, and live/dead cell biomass using ordinary least squares regression of log-transformed data. Lines were fit to C:P (BG:AP) and C:N (BG:[LAP+NAG]) enzyme ratios using the Standard Major Axis method (SMA) and to determine significant differences in the slopes of these lines.

Biofilm community 16S rRNA gene sequence data were checked for quality using CodonCode Aligner. High-quality sequences (containing $>400$ bases with PHRED scores $>20$ ) greater than 500 bp were exported to Greengenes (http://greengenes.lbl. gov) for alignment (NAST Alignment Tool; DeSantis et al. 2006) and chimera checking (Bellerophon Chimera Check Tool; Huber et al. 2004). The ARB software package was used to filter the sequences to a uniform length and to create a distance matrix of the aligned and filtered sequences (Ludwig et al. 2004). The distance matrix was analyzed in mothur (Schloss et al. 2009) to cluster sequences into OTUs, to generate rarefraction curves using a $97 \%$ DNA sequence similarity cutoff, to calculate the Chao1 estimate of richness, and to determine the abundance of each OTU in each sample. Mothur was also used to assign taxonomic classifications to each OTU using bacterial reference sequences from the SILVA rRNA database project.

The phylogeny of the bacterial 16S rRNA genes from the enrichment gradient was analyzed using UniFrac (Lozupone \& Knight 2005, Lozupone et al. 2006). Briefly, all aligned, high-quality sequences were added to a backbone phylogenetic tree of $\sim 6500$ bacterial 16S rRNA gene sequences (Hugenholtz 2002) using the parsimony add function in ARB (Ludwig et al. 2004). This tree was imported into UniFrac to calculate the UniFrac metric as described by Lozupone \& Knight (2005). Unweighted UniFrac hypothesis testing was performed to test whether the communities from the 5 treatments had the same structure. A principal coordinate analysis (PCA) was performed in UniFrac (Lozupone et al. 2006).

\section{RESULTS}

\section{Physical structure of the biofilm}

Mean AFDM values in the control, $2 \times$ and $4 \times$ enrichments ranged from $\sim 0.1$ to $0.25 \mathrm{mg} \mathrm{cm}^{-2}$ while values in the $8 \times$ and $10 \times$ enrichments ranged from $\sim 1.0$ to $1.25 \mathrm{mg} \mathrm{cm}^{-2}$ (Fig. 2). AFDM values for the control and $2 \times$ enrichment were similar and not statistically different $(p>0.05)$. The values for the $8 \times$ and $10 x$ enrichments were also similar to each other. The areal density of AFDM and DM responded in a roughly linear fashion to the resource gradient, with 23- and 18-fold increases $(b \pm 95 \% \mathrm{CI}$; $\mathrm{AFDM}=1.48 \pm 0.28, \mathrm{DM}=$ $1.31 \pm 0.29$ ), respectively, over the 10 -fold enrichment gradient (Fig. 3).

Confocal laser microscopy showed that biofilm from the control treatment was a dense layer of bacterial cells with minimal vertical development. Images from successive enrichments showed increasing vertical development driven by increasing abundance of filamentous growth forms interspersed with cocci and rodshaped cells (images not shown). As a result, the areal abundance of live and dead cells increased much more than AFDM in response to resource enrichment, with increments of 10-, 53-, 213- and 193-fold for areal abundance and 10-, 34-, 126- and-132 fold for AFDM, in the $2 \times, 4 \times, 8 \times$ and $10 \times$ enrichments, respectively $(b \pm$ $95 \% \mathrm{CI}_{\text {; }}$ abundance: $2.25 \pm 0.23$, AFDM: $2.05 \pm 0.18$ ) (Fig. 3). The live and dead cell fluorescence values for the control, $2 \times$ and $4 \times$ treatments were significantly different from one another and from the $8 x$ and $10 x$ treatments, which were not statistically different (Fig. 2). One of the 15 channels, channel $9-$ a $4 \times$ treatment - was a consistent outlier and was excluded from the analyses of biofilm physical structure and function. 


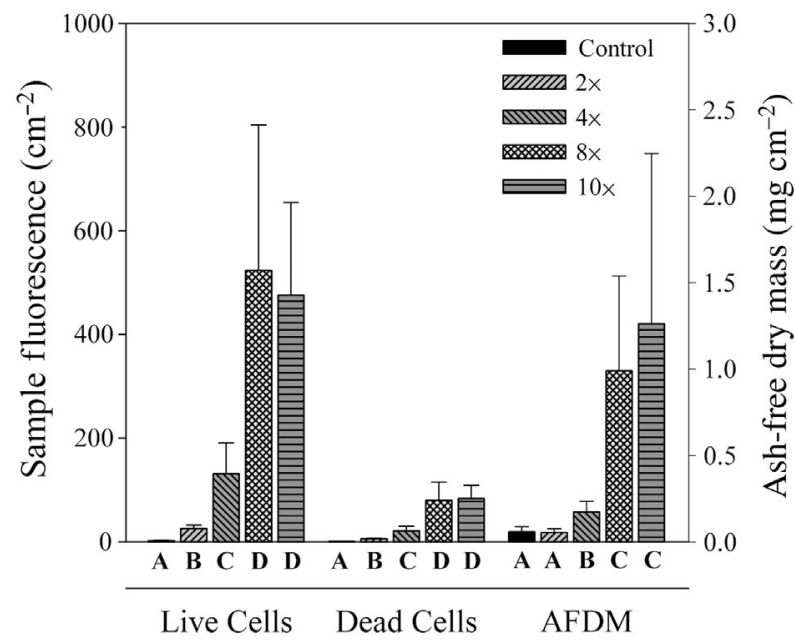

Fig. 2. Response of biomass to enrichment as measured by the fluorescence signal of live/dead biomass and ash-free dry mass (AFDM). Enrichment gradient: multiples of ambient concentration of dissolved organic carbon, $\sim 1.5 \mathrm{mg} \mathrm{l}^{-1}$. Values were obtained for all treatments; however, in some cases control values are too low to be seen in the figure. Values with the same letter are not significantly different at $\mathrm{p}<0.05$

\section{Biofilm function}

As biofilm biomass increased in response to enrichment, EEA increased exponentially (Fig. 3). In relative terms, EEA increased in the order AG, NAG, BG, LAP and AP (Fig. 4). For AG, activity in the control to $10 \times$ enrichment treatments ranged from 0.004 to $8.0 \mathrm{nmol}$ $\mathrm{h}^{-1} \mathrm{~cm}^{-2}$, respectively; for AP the corresponding range was 0.14 to $47 \mathrm{nmol} \mathrm{h}^{-1} \mathrm{~cm}^{-2}$. Response ratios for the $10 \times$ enrichment relative to the control treatment in-

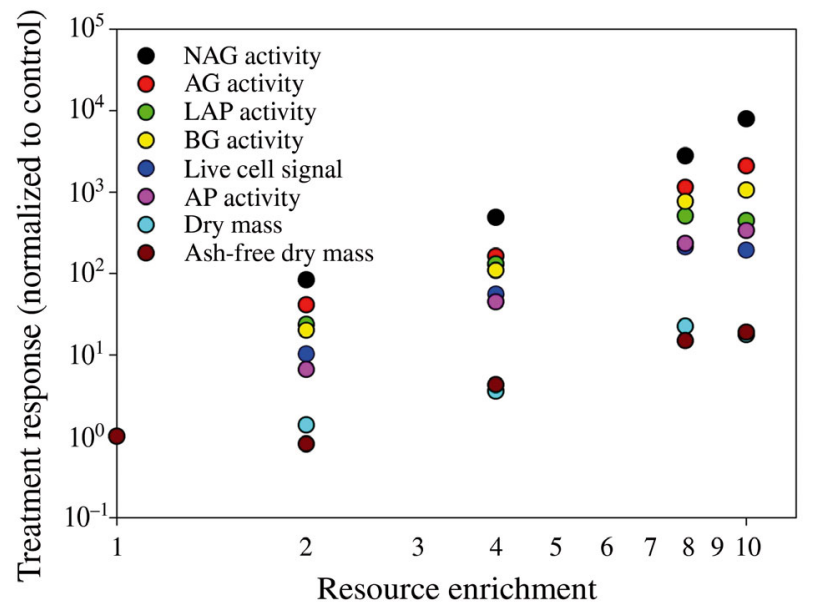

Fig. 3. Response ratios (normalized to control) of biofilm biomass and functional parameter responses to an enrichment gradient (see Fig. 2). The single dot at an enrichment level of 1 represents the control values for all 8 parameters. NAG: $N$ acetylglucosaminidase, AG: $\alpha$-glucosidase, LAP: leucine aminopeptidase, BG: $\beta$-glucosidase, AP: alkaline phosphatase creased in approximately the reverse order relative to the absolute EEA, with values of 350, 500, 1100, 2100 and 7900 for AP, LAP, BG, AG and NAG, respectively (Fig. 3). Exponential scaling exponents $(b \pm 95 \%$ CI) were $2.42 \pm 0.26,2.48 \pm 0.35,2.76 \pm 0.40,3.01 \pm 0.43$ and $3.46 \pm 0.52$ for AP, LAP, BG, AG and NAG, respectively (Fig. 3). Only 1 enzyme, LAP, reached a plateau at the $8 \times$ enrichment, with a slight decrease in activity found in the 10× enrichment (Fig. 4). For each enzyme, activity in the control treatment was significantly different from that in enrichment treatments, while activities in the $8 \times$ and $10 \times$ enrichment treatments were not significantly different (Fig. 4).

Across the enrichment gradient, ratios of the activities of $\mathrm{C}$-, $\mathrm{N}$ - and $\mathrm{P}$-acquiring enzymes, represented as BG:(LAP+NAG):AP, remained consistent at $\sim 1: 1: 1$ (Fig. 5). The standard major axis analysis of $\ln (B G)$ vs. $\ln (\mathrm{LAP}+\mathrm{NAG})$, and $\ln (\mathrm{BG}) \mathrm{vs} \cdot \ln (\mathrm{AP})$ across the enrichment gradient revealed significantly $(p<0.02)$ different slopes $( \pm 95 \% \mathrm{CI})$ of $1.09 \pm 0.05$ and $1.20 \pm 0.07$, respectively (Fig. 5).

\section{Composition of the biofilm community}

A total of 1902 high-quality partial 16S rRNA gene sequences were obtained (see Table S1 in the supplement at www.int-res.com/articles/suppl/a064p149_ supp.pdf). These sequences were distributed across the resource gradient treatments with 356, 397, 398, 400 and 351 sequences from the control, $2 \times, 4 \times, 8 \times$ and $10 \times$ enrichment treatments, respectively. A total of 293 OTUs were identified at the species level $(97 \%$ sequence similarity) with 168, 70, 69, 46 and 36 OTUs found in the control, $2 \times, 4 \times, 8 \times$ and $10 \times$ treatments, respectively. Rarefaction curves from the 4 enrichment treatments (97\% similarity cut-off) approached a plateau, indicating comprehensive sampling of the $16 \mathrm{~S}$ rRNA gene diversity amplified in these samples (Fig. $6)$. The rarefaction curve from the control treatment did not reach a plateau; however, the slope of this curve was decreasing - indicating that a substantial amount of the 16S rRNA gene diversity was successfully described (Fig. 6). Chao 1 estimates of species richness indicated that bacterial diversity progressively decreased with enrichment: the control, $2 \times, 4 \times$, $8 \times$ and $10 \times$ treatments had richness estimates $(97 \%$ sequence similarity) of 429 (95\% CI: 325 to 604), 136 (102 to 211), 105 (85 to 153), 96 (72 to 160) and 60 (47 to 100), respectively.

Representatives from 11 bacterial phyla and candidate divisions were found in the 1902 partial 16S rRNA gene sequences recovered. Of the 11 phyla detected, 9, 5, 2, 4 and 4 were represented in the control, $2 \times, 4 \times, 8 \times$ and $10 \times$ enrichment treatments, respectively 


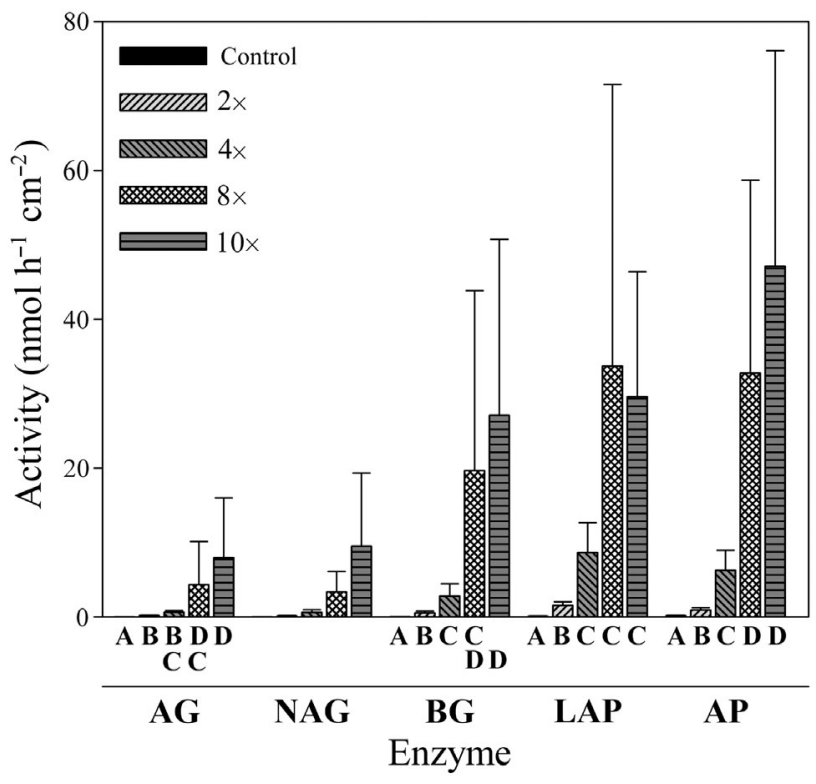

Fig. 4. Response of extracellular enzyme activities (see Fig. 3 for definitions) to an enrichment gradient (multiples of ambient concentration of dissolved organic carbon, $\sim 1.5 \mathrm{mg} \mathrm{l}^{-1}$ ). Values were obtained for all treatments; however, in some cases control values are too low to be seen in the figure. Values with the same letter are not significantly different at $\mathrm{p}<0.05$

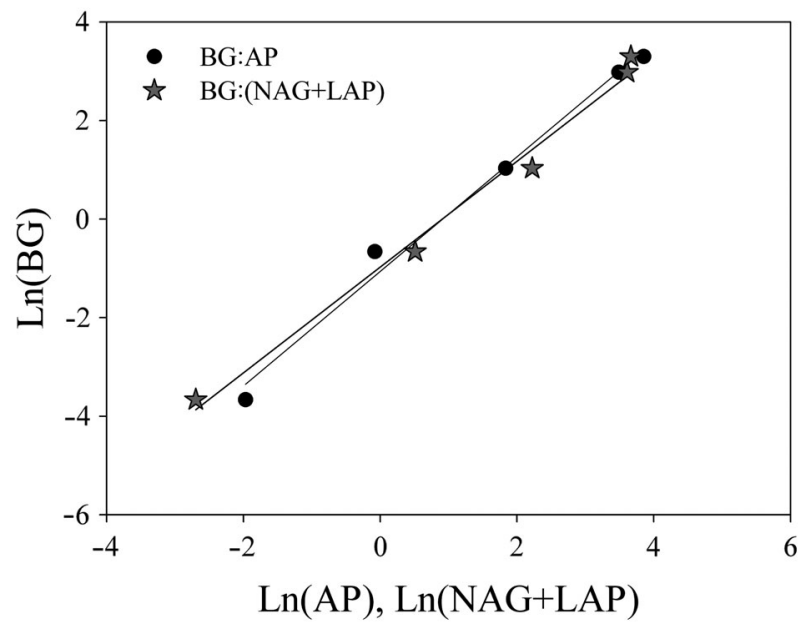

Fig. 5. Ln normalized activities of C-acquiring (BG) to $\mathrm{N}$-acquiring (NAG + LAP) enzymes, and C-acquiring (BG) to $\mathrm{P}$-acquiring (AP) enzymes (see Fig. 3 for definitions) for the enrichment gradient

(Fig. 7). An analysis of OTU overlap between treatments showed the least overlap between the control and 10x treatments (5 OTUs) and the most overlap between the $4 \times$ and $8 \times$ ( 30 OTUs) and the $8 \times$ and $10 \times$ (28 OTUs) treatments. In general, samples from treatments with increasingly divergent levels of enrichment shared a decreasing number of OTUs (Fig. 7). The unweighted UniFrac hypothesis testing analysis indicated that com-

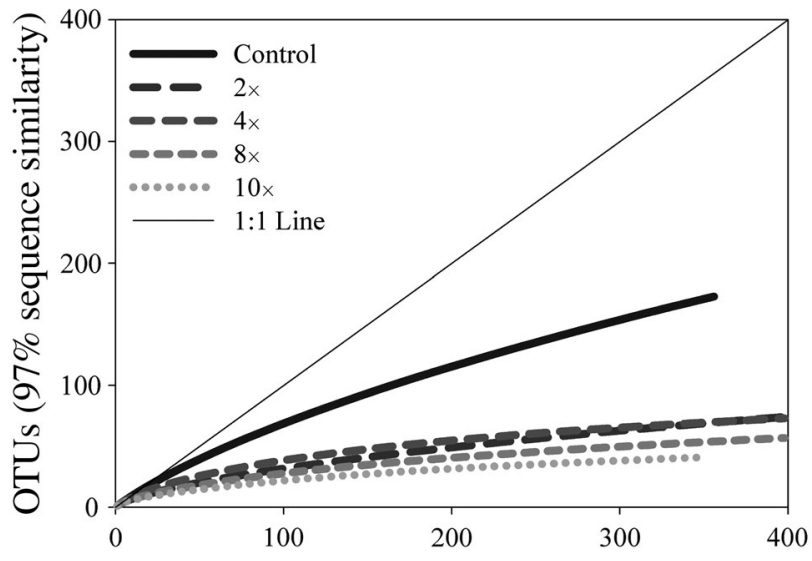

Fig. 6. Rarefaction curves created in mothur $(97 \%$ sequence similarity) for the bacterial communities from the control and the 4 enrichment treatments

munities from the 5 treatments were significantly different from one another $(p<0.005)$, with the exception of the $8 \times$ and $10 \times$ treatments. PCA results show relatively tight and distinctive grouping of sequences from the control treatment, from the $2 \times$ and $4 \times$ enrichment treatments and a grouping that includes sequences from the $8 \times$ and $10 \times$ treatments (Fig. 8). Principal coordinate 1 explained $28 \%$ of the variation in the samples and appeared to be well correlated with the eutrophication enrichment level as the sample clusters increased in enrichment from the left to the right side of the plot (Fig. 8).

Classification of the partial 16S rRNA gene sequences (mothur, SILVA taxonomy) revealed taxonomic shifts in the most frequently found sequences from each treatment. Sequences that could be identified to genus level were the most evenly distributed in the control treatment, with the greatest percentage of sequences from the Leptothrix (Betaproteobacteria), Rhodobacter (Alphaproteobacteria) and Flavobacterium (Bacteroidetes) genera. Sequences from the $2 \times$ enrichment were most commonly found in the Flectobacillus (Bacteroidetes), Arcicella (Bacteroidetes) and Leptothrix (Betaproteobacteria) genera. The $4 \times$ enrichment was composed of Rhodoferax (Betaproteobacteria), Arcicella (Bacteroidetes) and Flectobacillus (Bacteroidetes) genera. The $8 \times$ and $10 \times$ enrichments were populated mainly with sequences from the Aeromonas (Gammaproteobacteria), Janthinobacterium (Gammaproteobacteria), Flectobacillus (Bacteroidetes) and Rhodoferax (Betaproteobacteria) genera.

\section{DISCUSSION}

The bulk biomass of the heterotrophic biofilm community responded nonlinearly to enrichment with an exponent $(b)$ of $\sim 1.5$ for areal mass. Bacterial produc- 


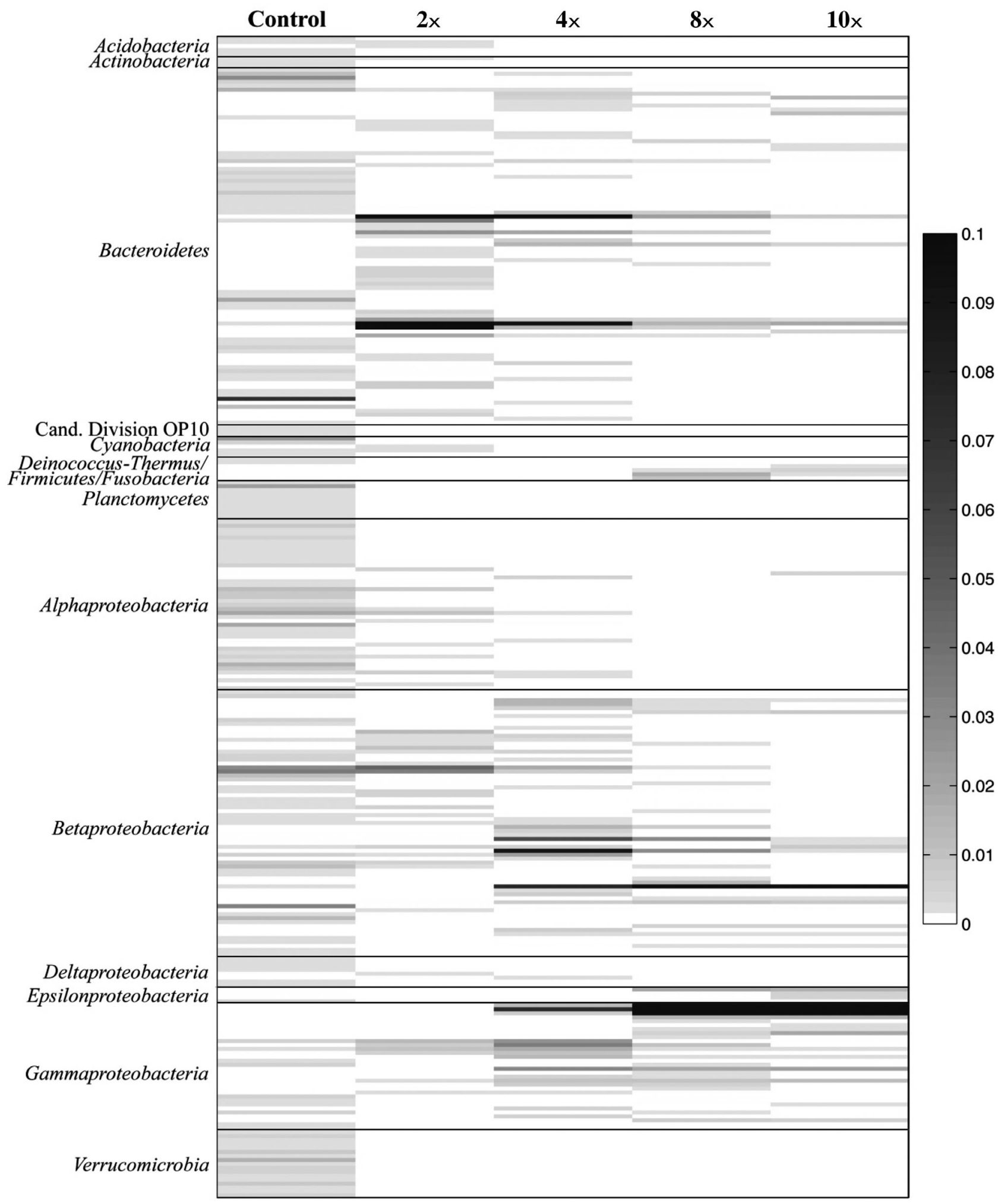

Fig. 7. Relative abundance of bacterial 16S rRNA gene sequences ordered by taxonomy (SILVA classification) and enrichment level (multiples of ambient concentration of dissolved organic carbon, $\sim 1.5 \mathrm{mg} \mathrm{l}^{-1}$ ). Each row represents an OTU defined at $97 \%$ sequence similarity cutoff. The shading of each OTU bar represents the relative abundance of the sequences in each OTU for each enrichment treatment according to the key on the right-hand side. The phylum or candidate division of each OTU is indicated on the left and demarcated by thin black horizontal lines 




Fig. 8. Principal coordinate analysis performed in UniFrac for the bacterial communities of the 15 individual enrichment channels (triplicates of control [ $1 \times], 2 \times, 4 \times, 8 \times$ and $10 \times$ multiples of the ambient concentration of dissolved organic carbon, $\sim 1.5 \mathrm{mg} \mathrm{l}^{-1}$ ). Analysis was performed using the UniFrac unweighted analysis option

tivity was not directly measured in this study; however, live cell biomass, which can be viewed as a surrogate for productivity, increased faster than bulk biomass, with an exponent of 2.3. Comparable results for cell density were reported by Mohamed et al. (1998) who found that a $15 \%$ increment in available DOC led to a $3.6 \times$ increment in bacterial density in a heterotrophic biofilm $(b \sim 2)$. A synoptic comparison of 15 marine systems showed that planktonic bacterial biomass and abundance increased only $10 \times$ over a $2800 \times$ range in primary production ( $b \sim 0.01$ ) (Thelaus et al. 2008). Bacterial productivity was more dynamic, showing a $1000 \times$ response in relation to the $2800 \times$ change in primary production $(b \sim 0.8)$. Planktonic responses to experimental enrichments over much smaller ranges show similar results. Jansson et al. (2006) and Joint et al. (2002) reported that $2 \times$ and $32 \times$ enrichments of $C, N$ and $\mathrm{P}$ in planktonic mesocosms resulted in $2 \times$ and $17 \times$ increases in bacterial production $(b \sim 0.7)$, and a $1.5 \times$ and $2 \times$ increase in bacterial biomass $(b \sim 0.1)$, respectively. These findings suggest that, for both planktonic and heterotrophic biofilm communities, biomass accrual stimulated by nutrient enrichment lags behind increases in productivity; however, the rate of change between these 2 types of community is drastically different. Our biofilm communities responded to a $10 \times$ enrichment with a 20-fold increase in AFDM and a 190-fold increase in live cell biomass. Given the responses discussed above, the expected response of planktonic communities to a $10 \times$ enrichment would be an approximate 0.04 -fold increase in biomass and a 3.5-fold increase in productivity.
As biofilm bulk biomass increased in response to enrichment with resources, the activity of enzymes responsible for $\mathrm{C}, \mathrm{N}$ and $\mathrm{P}$ acquisition increased more quickly (range of $b \sim 2.4$ to 3.5). These results are generally consistent with previous biofilm studies that used single-level enrichments. Modest 15 to $20 \%$ increases in $\mathrm{C}, \mathrm{N}$ and $\mathrm{P}$ resulted in 3 - to 200 -fold increases $(b \sim 1.2$ to 3 ) in the functional processes of a mixed heterotrohic/autotrophic biofilm, including the utilization of carbon and nitrogen compounds (Chenier et al. 2003, 2006) and nitrification and denitrification rates (Chenier et al. 2003, 2006). In contrast to biofilms, net functional processes in planktonic microbial communities exhibit muted responses to increased resources. Several mesocosm studies have used additions of glucose to stimulate the removal of nitrogen by bacterioplankton; the net response ratios appear to be well below 1, suggesting that C enrichment impacted these functions minimally (Shiah \& Ducklow 1995, Joint et al. 2002, Jansson et al. 2006). These results suggest that the differing magnitude of biomass/production responses of biofilm and planktonic communities to altered resources translates to the net functional responses of these communities. A given level of enrichment results in a smaller functional increase in planktonic communities, as measured by extracellular enzyme activities; however, the activity-to-production or activity-to-biomass ratios for the 2 types of community are similar (Sinsabaugh et al. 2010). This similarity is evident when turnover (\%biomass $\mathrm{d}^{-1}$ ) is compared across a wide variety of attached and planktonic bacterial communities. Biofilm turnover for environments - including decaying leaf litter, streams, mesocosm wetlands and tropical coastal lagoons-range from $\sim 0.02$ to $4000 \% \mathrm{~d}^{-1}$ with a median value of $\sim 48 \%$ $\mathrm{d}^{-1}$ (see the summary table in $\mathrm{Su}$ et al. 2007, and see Thomaz \& Esteves 1997a,b, Törnblom \& Søndergaard 1999, Carr et al. 2005, Tao et al. 2007). If 2 extreme outliers are removed from the 23 measurements gathered from the available literature, mean and median biofilm turnovers are 48 and $30 \% \mathrm{~d}^{-1}$ respectively. Bacterioplankton turnover for lakes and the open ocean ranges from $\sim 3$ to $180 \% \mathrm{~d}^{-1}$ with mean and median values of 43 and $33 \% \mathrm{~d}^{-1}$ respectively (Hyun et al. 1998, Torréton et al. 2002, Hyun \& Kim 2003, Chen et al. 2005, Hyun \& Yang 2005, Gao et al. 2007). Thus, while significant variability exists, median and mean turnover rates for the 2 types of community are very similar.

The responses of planktonic and biofilm communities to nutrient enrichment reflect their physical and community structures and the fate of their products. Bacterioplankton biomass increases moderately in response to increased resources, while production and predation increase very rapidly, with total predation increasing 1000-fold, and predation per unit of bacter- 
ial biomass increasing 100 -fold, over a 2800 -fold range in primary productivity (Thelaus et al. 2008). Thus, although bacterioplankton production rates are high, predation eliminates much of this biomass and is a primary factor controlling turnover rates. In biofilm communities, biomass increases moderately with increasing resources $(b \sim 1.5)$. However, in our study, the activity of enzymes responsible for the depolymerization of senescent material increased much more rapidly than biomass, resulting in the rapid internal cycling of materials. While grazing can be important in regulating biofilms (Huws et al. 2005), attached bacteria produce chemical defenses that protect the communities from eukaryotic predation (Weitere et al. 2005, Matz et al. 2008) and modify their organization to create grazing-resistant structures (Wey et al. 2008). These results suggest that turnover in biofilms is a result of internal cycling supported by biofilm structural and community responses to enrichment. Structurally, increased biofilm thickness protects extracellular enzymes from being washed out of the system by downstream flow, and it allows biofilms to concentrate nutrients (Tsuchiya et al. 2009) and energy-yielding materials (Battin et al. 1999) — which are dispersed in planktonic communities. This protection probably also encourages the production of extracellular enzymes by quorum sensing (DeAngelis et al. 2008, Decho et al. 2010), diffusion sensing (Redfield 2002), or efficiency sensing (Hense et al. 2007), which occur when concentrations of small, energy-inexpensive signal molecules reach threshold levels, inducing the transcription of large, energy-expensive extracellular enzymes. The dramatic increase in EEA may also be linked to differential rates of enzyme expression related to changes in bacterial community composition (Martinez et al. 1996). Thus, although the present study lacked the resolution to differentiate between several possible underlying mechanisms, heterotrophic biofilm development is highly responsive to the availability of resources, effectively storing (Tsuchiya et al. 2009) and cycling available resources. Ultimate limits are probably imposed by physicochemical constraints such as shear strength and diffusion gradients (Battin et al. 2003, Besemer et al. 2007) - conditions likely to be found in biofilms in later successional stages rather than in the communities, described in the present study, that developed in $3 \mathrm{wk}$.

Comparing the responses of planktonic and heterotrophic biofilms to enrichment is potentially complicated by the autotrophic component present in planktonic systems that was absent from the current experiment. Our biofilm communities more closely resemble the heterotrophic microbial communities found in streams or microenvironments with low-light conditions. Numerous studies have compared the structure and function of heterotrophic biofilms to the mixed heterotrophic/autotrophic communities found in systems with adequate light to stimulate algal growth. Heterotrophic biofilms have lower bacterial abundances (Roman \& Sabater 1999, Romaní et al. 2004, Ylla et al. 2009) and altered community compositions (Sinsabaugh \& Linkins 1988, Ylla et al. 2009) when compared to biofilms grown in the light. Functional comparisons of these 2 types of biofilm reveal complex heterotrophic/autotrophic interactions. In general, heterotrophic biofilms are dependent on exogenous carbon sources: they respond rapidly and efficiently to simple carbon inputs, indicating a deficit of labile carbon (Romaní et al. 2004), and they have high ratios of hemicelluloses to cellobiose consistent with a reliance on complex carbon sources when labile sources are unavailable (Roman \& Sabater 1999). In contrast, bacteria in lightgrown biofilms are more dependent on autotrophic production to supply metabolic substrates (Roman \& Sabater 1999, Romaní et al. 2004). Thus, they are probably indirectly responsive to increases in nutrients via labile organic molecules leaked or secreted from elevated autotrophic production (Ylla et al. 2009). Differences in EEA between the 2 types of community are less clear. Some autotrophic communities have higher areal (Roman \& Sabater 1999, 2000, Romaní et al. 2004, Ylla et al. 2009) and per cell extracellular enzyme activities (Roman \& Sabater 1999); however, this does not always hold true (Sinsabaugh \& Linkins 1988, Jones \& Lock 1993). Thus, biofilms grown in the light under a similar enrichment gradient would probably respond somewhat differently than the heterotrophic communities studied here due to heterotrophic/autotrophic interactions. However, the general pattern of greater biofilm biomass, productivity, and functional responses as compared to planktonic communities - is likely to hold for several reasons. First, phototrophic biofilms have been shown to respond positively to nutrient additions, given adequate light (Johnson et al. 2009). Second, in each comparison of light-versus-dark biofilms discussed above, the light-grown biofilms have had higher bacterial abundance and similar or higher activity. Third, in the very few cases in which paired heterotrophic and autotrophic biofilms have both received enrichment, bacteria from both types of community have responded similarly (Sobczak 1996, Ylla et al. 2009).

Unlike biomass and activity, which increased rapidly with the availability of resources, enrichment led to a decreased richness of bacterial OTUs. Numerous studies have shown that enrichment alters the general community structure of bacterial biofilm and planktonic communities (Lebaron et al. 2001, Schäfer et al. 2001, Chenier et al. 2003, 2006, Haukka et al. 2006), but resolution has been limited. Declines in the richness of 
bacterioplankton (Carlson et al. 2002, Bertoni et al. 2008), or in their evenness (Sipura et al. 2005), with enrichment have been observed in some planktonic studies, supporting the trend observed in the present study.

Enrichment also led to dramatic changes in the composition of bacterial communities. Moderate enrichment $(2 \times)$ resulted in substantial shifts in the community composition, suggesting that stream biofilm communities from oligotrophic systems are highly responsive to enrichment. In the control treatment, Bacteroidetes, Alphaproteobacteria, Betaproteobacteria and Gammaproteobacteria were present in approximately equal numbers, with Verrucomicrobia and Actinobacteria present at lower frequencies. These phyla are typical of those found in other stream biofilm communities (Brümmer et al. 2003, Besemer et al. 2007, Kobayashi et al. 2009, Ylla et al. 2009). In contrast, Betaproteobacteria and Gammaproteobacteria were the dominant phyla in the highest levels of enrichment, and OTUs related to Verrucomicrobia and Actinobacteria were absent. The shift to a Gammaproteobacteriadominated community has been observed in other enrichment studies (Pinhassi \& Berman 2003) and thus the observed decline in diversity may be attributable to the dominance of opportunistic weed-like species.

The dominant genera from each level of enrichment also changed dramatically; however, the majority of these genera are classified as chemoorganotrophs. Two of the dominant genera found in the control treatment, Flavobacterium and Leptothrix, are dominated by aerobic species, while the third genus, Rhodobacter, contains photoautotrophic, photoheterotrophic and chemotrophic organisms. Relatives of all 3 genera - Flavobacterium (Kobayashi et al. 2009), Leptothrix (Brümmer et al. 2003, Ylla et al. 2009) and Rhodobacter (Ylla et al. 2009) - have been found in other stream biofilms. Interestingly, Rhodobacter was found in another dark-grown biofilm (Ylla et al. 2009). The dominant genera in the $8 \times$ and 10x enrichments - Aeromonas, Janthinobacterium and Arcicella - have been found in other stream biofilms (Kobayashi et al. 2009); they consist primarily of chemoorganotrophs and are aerobes, with the exception of Aeromonas, which is a facultative anaerobe. The presence of this facultative anaerobe suggests that oxygen may have been limiting in the well-developed biofilms that resulted from enrichment.

Changes in the composition of the bacterial community have been related to enrichment in other aquatic systems. Ylla et al. (2009) found that the addition of glucose eliminated OTUs related to Actinobacteria from a community of heterotrophic bacteria, a pattern observed in our enrichment study. Kobayashi et al. (2009) used bacterial community profiling techniques to synoptically sample 2 rivers in Japan. Significant changes in the patterns of bacterial community composition were most strongly related to anthropogenic nitrogen inputs; however, insufficient sequencing prevented a determination of which bacterial genera were responsive to enrichment. A similar study of the Elbe River in Germany, and a highly polluted tributary, found that pollution primarily impacted the abundance rather than the presence/absence of bacterial genera (Brümmer et al. 2003). Relatives of the most common genera from the control and enrichment treatments described above have been found in biofilms from globally distributed locations. This ubiquity suggests that these genera are members of a cosmopolitan freshwater biofilm cluster.

In this study of heterotrophic bacterial biofilms, an enrichment gradient produced a productivity gradient; however, OTU richness declined at all levels of enrichment. This was surprising as richness was expected to increase with the number of physical and chemical niches that form as biofilms mature and thicken, a response that would have been consistent with the species-energy hypothesis (Allen et al. 2002). These findings suggest that, for heterotrophic bacterial communities, an increase in total available energy increases the absolute live-cell biomass as well as the live-to-dead cell ratio; however, the total number of viable bacterial populations decreases. Thus, the diversity of resources, rather than the total resources available, may be more important for structuring these communities. This is consistent with the results from 2 studies: (1) a laboratory culturing experiment which found that bacterial diversity had a unimodal relationship to productivity in heterogeneous - but not in homogeneous - environments (Kassen et al. 2000), and (2) a study involving a high-carbon soil environment in which resource heterogeneity was thought to drive diversity patterns (Zhou et al. 2002). Additionally, aquatic microbial communities have known sensitivities to varying carbon substrates. In stream biofilms, the abundance of cells from the domain bacteria and several phyla, sub-phyla, and species, shifted in response to the additions of glucose and to seasonal changes in available DOM (Olapade \& Leff 2005, 2006), and the composition of the community changed rapidly in response to inoculation with a variety of simple and complex DOM substrates (Wu et al. 2009, Rodrigues et al. 2010). These studies also found that leaf leachate stimulated or suppressed various members of the microbial community, indicating differential utilization of the potential DOM pools (Olapade \& Leff 2005, 2006). DOM utilization preferences have also been described for a variety of bacterial phyla, sub-phyla, and species in marine (Cottrell \& Kirchman 2000), estuarine (Covert \& Moran 2001) and stream biofilm (McNamara \& Leff 2004, Lear et al. 2009) communities. 


\section{CONCLUSIONS}

Stream biofilm communities play a significant role in processing nutrient and organic matter inputs to streams. As streams are enriched with nutrients and DOC, the community diversity and structure of these biofilms, as well as their ability to perform functional processes, undergo significant changes, with some similarities to those observed in planktonic communities. In both planktonic and biofilm communities, enrichment stimulates greater increases in productivity than in biomass; however, the magnitude of this response was much larger in the heterotrophic biofilms in our study. In planktonic communities, increased production is transferred up the food web where it stimulates secondary production and respiration, with modest increases in planktonic biomass. In biofilms, the products of nutrient enrichment (e.g. cells, enzymes, extracellular polymers) tend to accumulate, initiating a structural and social positive feedback that increases biomass and potential EEA. This positive feedback is eventually truncated by structural failures (sloughing) that export material downstream, or by invertebrate grazing. Further study of the effects of enrichment on biofilms using a complex carbon source, as opposed to the readily labile carbon source used here, would provide additional insights into productivity-diversity relationships as a more diverse community may be necessary to break down various fractions of a more complex carbon pool.

Acknowledgements. We acknowledge E. Driscoll, S. Hicks and M. Stursova for field and laboratory assistance, and D. Colman for assisting with manuscript preparation. The Albuquerque Academy provided the research location for this experiment. Sequencing for this study was performed at the Genome Sequencing Center at Washington University School of Medicine in St. Louis, Missouri. Confocal microscopy was made possible through funding from the W. M. Keck Foundation for the UNM Keck Nanofluidics Laboratory. Funding for this project was provided by: The New Mexico Water Resources Research Institute Student Research Grant, T\&E Inc. Grants for Conservation Biology Research, and a University of New Mexico Research Allocations Committee Grant. Support was provided to D.J.V.H. through the Alvin R. and Caroline G. Grove Doctoral Scholarship. The U.S. National Science Foundation provided support to C.N.D. through the Experimental Program to Stimulate Competitive Research (EPSCoR) (EPS 0814449), to R.L.S. through the NSF EaGER program, and to C.N.D., and D.J.V.H. through the Sevilleta Long-Term Ecological Research (LTER) Project (DEB-0620482). This is publication number SEV 559 from the Sivelleta LTER project.

\section{LITERATURE CITED}

Alakomi HL, Matto J, Virkajarvi I, Saarela M (2005) Application of a microplate scale fluorochrome staining assay for the assessment of viability of probiotic preparations. J Microbiol Methods 62:25-35

Allen AP, Brown JH, Gillooly JF (2002) Global biodiversity, biochemical kinetics, and the energetic-equivalence rule. Science 297:1545-1548

Battin TJ, Butturini A, Sabater F (1999) Immobilization and metabolism of dissolved organic carbon by natural sediment biofilms in a Mediterranean and temperate stream. Aquat Microb Ecol 19:297-305

Battin TJ, Kaplan LA, Newbold JD, Hansen CME (2003) Contributions of microbial biofilms to ecosystem processes in stream mesocosms. Nature 426:439-442

Beloin C, Ghigo JM (2005) Finding gene-expression patterns in bacterial biofilms. Trends Microbiol 13:16-19

Bertoni R, Callieri C, Balseiro E, Modenutti B (2008) Susceptibility of bacterioplankton to nutrient enrichment of oligotrophic and ultraoligotrophic lake waters. J Limnol 67: 120-127

Besemer K, Singer G, Limberger R, Chlup AK and others (2007) Biophysical controls on community succession in stream biofilms. Appl Environ Microbiol 73:4966-4974

Brümmer IHM, Felske A, Wagner-Döbler I (2003) Diversity and seasonal variability of $\beta$-Proteobacteria in biofilms of polluted rivers: analysis by temperature gradient gel electrophoresis and cloning. Appl Environ Microbiol 69: 4463-4473

Carlson CA, Giovannoni SJ, Hansell DA, Goldberg SJ and others (2002) Effect of nutrient amendments on bacterioplankton production, community structure, and DOC utilization in the northwestern Sargasso Sea. Aquat Microb Ecol 30:19-36

Carr GM, Morin A, Chambers PA (2005) Bacteria and algae in stream periphyton along a nutrient gradient. Freshw Biol 50:1337-1350

Chen CC, Shiah FK, Lee HJ, Li KY and others (2005) Phytoplankton and bacterioplankton biomass, production and turnover in a semi-enclosed embayment with spring tide induced upwelling. Mar Ecol Prog Ser 304:91-100

Chenier MR, Beaumier D, Roy R, Driscoll BT, Lawrence JR, Greer CW (2003) Impact of seasonal variations and nutrient inputs on nitrogen cycling and degradation of hexadecane by replicated river biofilms. Appl Environ Microbiol 69:5170-5177

Chenier MR, Beaumier D, Fortin N, Roy R, Driscoll BT, Lawrence JR, Greer CW (2006) Influence of nutrient inputs, hexadecane and temporal variations on denitrification and community composition of river biofilms. Appl Environ Microbiol 72:575-584

Cole JJ, Findlay S, Pace ML (1988) Bacterial production in fresh and saltwater ecosystems: a cross-system overview. Mar Ecol Prog Ser 43:1-10

Costerton JW, Lewandowski Z, Caldwell DE, Korber DR, Lappinscott HM (1995) Microbial biofilms. Annu Rev Microbiol 49:711-745

Cottrell MT, Kirchman DL (2000) Natural assemblages of marine proteobacteria and members of the CytophagaFlavobacter cluster consuming low- and high-molecularweight dissolved organic matter. Appl Environ Microbiol 66:1692-1697

Covert JS, Moran MA (2001) Molecular characterization of estuarine bacterial communities that use high- and lowmolecular-weight fractions of dissolved organic carbon. Aquat Microb Ecol 25:127-139

> Davey ME, O'Toole GA (2000) Microbial biofilms: from ecology to molecular genetics. Microbiol Mol Biol Rev 64: $847-867$

DeAngelis KM, Lindow SE, Firestone MK (2008) Bacterial quorum sensing and nitrogen cycling in rhizosphere soil. FEMS Microbiol Ecol 66:197-207

Decho AW, Norman RS, Visscher PT (2010) Quorum sensing 
in natural environments: emerging views from microbial mats. Trends Microbiol 18:73-80

DeSantis TZ, Hugenholtz P, Keller K, Brodie EL and others (2006) NAST: a multiple sequence alignment server for comparative analysis of 16S rRNA genes. Nucleic Acids Res 34:W394-W399

Dufour PH, Torréton JP (1996) Bottom-up and top-down control of bacterioplankton from eutrophic to oligotrophic sites in the tropical northeastern Atlantic Ocean. DeepSea Res I 43:1305-1320

Falster DS, Warton DI, Wright IJ (2006) SMATR: Standardized major axis tests and routines, ver 2.0. http://www.bio.mq. edu.au/ecology/SMATR/

Gao G, Qin BQ, Sommaruga R, Psenner R (2007) The bacterioplankton of Lake Taihu, China: abundance, biomass, and production. Hydrobiologia 581:177-188

Gasol JM, Pedrós-Alió C, Vaqué D (2002) Regulation of bacterial assemblages in oligotrophic plankton systems: results from experimental and empirical approaches. Antonie Leeuwenhoek 81:435-452

Hall-Stoodley L, Costerton JW, Stoodley P (2004) Bacterial biofilms: from the natural environment to infectious diseases. Nat Rev Microbiol 2:95-108

Haukka K, Kolmonen E, Hyder R, Hietala J and others (2006) Effect of nutrient loading on bacterioplankton community composition in lake mesocosms. Microb Ecol 51:137-146

- Hense BA, Kuttler C, Mueller J, Rothballer M, Hartmann A, Kreft JU (2007) Does efficiency sensing unify diffusion and quorum sensing? Nat Rev Microbiol 5:230-239

Hobbie JE, Cole JJ (1984) Response of a detrital foodweb to eutrophication. Bull Mar Sci 35:357-363

> Huber T, Faulkner G, Hugenholtz P (2004) Bellerophon: a program to detect chimeric sequences in multiple sequence alignments. Bioinformatics 20:2317-2319

Hugenholtz P (2002) Exploring prokaryotic diversity in the genomic era. Genome Biol 3:reviews0003.1-reviews0003.8

Huws SA, McBain AJ, Gilbert P (2005) Protozoan grazing and its impact upon population dynamics in biofilm communities. J Appl Microbiol 98:238-244

Hyun JH, Kim KH (2003) Bacterial abundance and production during the unique spring phytoplankton bloom in the central Yellow Sea. Mar Ecol Prog Ser 252:77-88

Hyun JH, Yang EJ (2005) Meso-scale spatial variation in bacterial abundance and production associated with surface convergence and divergence in the NE equatorial Pacific. Aquat Microb Ecol 41:1-13

Hyun JH, Choi JK, Yang EJ, Kim KH (1998) Biomass and productivity of bacterioplankton related to surface water divergence in the northeast equatorial Pacific Ocean. J Microbiol 36:151-158

Jansson M, Bergström AK, Lymer D, Vrede K, Karlsson J (2006) Bacterioplankton growth and nutrient use efficiencies under variable organic carbon and inorganic phosphorus ratios. Microb Ecol 52:358-364

Johnson LT, Tank JL, Dodds WK (2009) The influence of land use on stream biofilm nutrient limitation across eight North American ecoregions. Can J Fish Aquat Sci 66: 1081-1094

Joint I, Henriksen P, Fonnes GA, Bourne D, Thingstad TF, Riemann B (2002) Competition for inorganic nutrients between phytoplankton and bacterioplankton in nutrient manipulated mesocosms. Aquat Microb Ecol 29:145-159

Jones SE, Lock MA (1993) Seasonal determinations of extracellular hydrolytic activites in heterotrophic and mixed heterotrophic/autotrophic biofilms from two contrasting rivers. Hydrobiologia 257:1-16

Kassen R, Buckling A, Bell G, Rainey PB (2000) Diversity peaks at intermediate productivity in a laboratory microcosm. Nature 406:508-512

Kobayashi Y, Kim C, Yoshimizu C, Kohzu A, Tayasu I, Nagata $\mathrm{T}$ (2009) Longitudinal changes in bacterial community composition in river epilithic biofilms: influence of nutrients and organic matter. Aquat Microb Ecol 54:135-152

Lane DJ (1991) 16S/23S rRNA sequencing. In: Stackebrandt E, Goodfellow M (eds) Nucleic acid techniques in bacterial systematics. John Wiley, Chichester, p 115-175

Lear G, Turner SJ, Lewis GD (2009) Effect of light regimes on the utilisation of an exogenous carbon source by freshwater biofilm bacterial communities. Aquat Ecol 43: 207-220

Lebaron P, Servais P, Troussellier M, Courties C and others (2001) Microbial community dynamics in Mediterranean nutrient-enriched seawater mesocosms: changes in abundances, activity and composition. FEMS Microbiol Ecol 34:255-266

Lozupone C, Knight R (2005) UniFrac: a new phylogenetic method for comparing microbial communities. Appl Environ Microbiol 71:8228-8235

Lozupone C, Hamady M, Knight R (2006) UniFrac - an online tool for comparing microbial community diversity in a phylogenetic context. BMC Bioinformatics 7:371-384

Ludwig W, Strunk O, Westram R, Richter L and others (2004) ARB: a software environment for sequence data. Nucleic Acids Res 32:1363-1371

Martinez J, Smith DC, Steward GF, Azam F (1996) Variability in ectohydrolytic enzyme activities of pelagic marine bacteria and its significance for substrate processing in the sea. Aquat Microb Ecol 10:223-230

Matz C, Webb JS, Schupp PJ, Phang SY (2008) Marine biofilm bacteria evade eukaryotic predation by targeted chemical defense. PLoS ONE 3:e2744

McNamara CJ, Leff LG (2004) Response of biofilm bacteria to dissolved organic matter from decomposing maple leaves. Microb Ecol 48:324-330

Mitchell KR, Takacs-Vesbach CD (2008) A comparison of methods for total community DNA preservation and extraction from various thermal envrionments. $\mathrm{J}$ Ind Microbiol Biotechnol 35:1139-1147

- Mohamed MN, Lawrence JR, Robarts RD (1998) Phosphorus limitation of heterotrophic biofilms from the Fraser River, British Columbia, and the effect of pulp mill effluent. Microb Ecol 36:121-130

> Olapade OA, Leff LG (2005) Seasonal response of stream biofilm communities to dissolved organic matter and nutrient enrichments. Appl Environ Microbiol 71:2278-2287

Olapade OA, Leff LG (2006) Influence of dissolved organic matter and inorganic nutrients on the biofilm bacterial community on artificial substrates in a northeastern Ohio, USA, stream. Can J Microbiol 52: 540-549

Oviatt CA, Keller AA, Sampou PA, Beatty LL (1986) Patterns of productivity during eutrophication: a mesocosm experiment. Mar Ecol Prog Ser 28:69-80

Parsek MR, Fuqua C (2004) Biofilms 2003: emerging themes and challenges in studies of surface-associated microbial life. J Bacteriol 186:4427-4440

Pinhassi J, Berman T (2003) Differential growth response of colony-forming $\alpha$ - and $\gamma$-Proteobacteria in dilution culture and nutrient addition experiments from Lake Kinneret (Israel), the Eastern Mediterranean Sea, and the Gulf of Eilat. Appl Environ Microbiol 69:199-211

Redfield RJ (2002) Is quorum sensing a side effect of diffusion sensing? Trends Microbiol 10:365-370

Rodrigues AL, Pereira MA, Janknecht P, Brito AG, Nogueira R (2010) Biofilms formed on humic substances: response to 
flow conditions and carbon concentrations. Bioresour Technol 101:6888-6894

Romaní AM, Sabater S (1999) Effect of primary producers on the heterotrophic metabolism of a stream biofilm. Freshw Biol 41:729-736

Romaní AM, Sabater S (2000) Influence of algal biomass on extracellular enzyme activity in river biofilms. Microb Ecol 40:16-24

Romaní AM, Guasch H, Muñoz I, Ruana J and others (2004) Biofilm structure and function and possible implications for riverine DOC dynamics. Microb Ecol 47:316-328

Schäfer H, Bernard L, Courties C, Lebaron P and others (2001) Microbial community dynamics in Mediterranean nutrient-enriched seawater mesocosms: Changes in the genetic diversity of bacterial populations. FEMS Microbiol Ecol 34:243-253

Schloss PD, Westcott SL, Ryabin T, Hall JR and others (2009) Introducing mothur: open source, platform-independent, community-supported software for describing and comparing microbial communities. Appl Environ Microbiol 75:7537-7541

Shiah FK, Ducklow HW (1995) Regulation of bacterial abundance and production by substrate supply and bacterivory: a mesocosm study. Microb Ecol 30:239-255

Singer G, Besemer K, Hodl I, Chlup A, Hochedlinger G, Stadler P, Battin TJ (2006) Microcosm design and evaluation to study stream microbial biofilms. Limnol Oceanogr Methods 4:436-447

Sinsabaugh RL, Linkins AE (1988) Exoenzyme activity associated with lotic epilithon. Freshw Biol 20:249-261

Sinsabaugh RL, Findlay S, Franchini P, Fisher D (1997) Enzymatic analysis of riverine bacterioplankton production. Limnol Oceanogr 42:29-38

Sinsabaugh RL, Van Horn DJ, Follstad Shah JJ, Findlay S (2010) Ecoenzymatic stoichiometry in relation to productivity for freshwater biofilm and plankton communities. Microb Ecol 60:885-893

Sipura J, Haukka K, Helminen H, Lagus A, Suomela J, Sivonen K (2005) Effect of nutrient enrichment on bacterioplankton biomass and community composition in mesocosms in the Archipelago Sea, northern Baltic. J Plankton Res 27:1261-1272

Smith EM, Prairie YT (2004) Bacterial metabolism and growth efficiency in lakes: the importance of phosphorus availability. Limnol Oceanogr 49:137-147

Sobczak WV (1996) Epilithic bacterial responses to variations in algal biomass and labile dissolved organic carbon during biofilm colonization. J N Am Benthol Soc 15:143-154

Stelzer RS, Heffernan J, Likens GE (2003) The influence of dissolved nutrients and particulate organic matter quality on microbial respiration and biomass in a forest stream. Freshw Biol 48:1925-1937

Su R, Lohner RN, Kuehn KA, Sinsabaugh R, Neely RK (2007) Microbial dynamics associated with decomposing Typha angustifolia litter in two contrasting Lake Erie coastal wetlands. Aquat Microb Ecol 46:295-307
Tao WD, Hall KJ, Duff SJB (2007) Microbial biomass and heterotrophic production of surface flow mesocosm wetlands treating woodwaste leachate: responses to hydraulic and organic loading and relations with mass reduction. Ecol Eng 31:132-139

Thelaus J, Haecky P, Forsman M, Andersson A (2008) Predation pressure on bacteria increases along aquatic productivity gradients. Aquat Microb Ecol 52:45-55

Thomaz SM, Esteves FA (1997a) Bacterial dynamics in periphyton from different regions of a tropical coastal lagoon. Arch Hydrobiol 139:495-507

Thomaz SM, Esteves FD (1997b) Secondary productivity $\left({ }^{3} \mathrm{H}\right.$ leucine and ${ }^{3} \mathrm{H}$-thymidine incorporation), abundance and biomass of the epiphytic bacteria attached to detritus of Typha domingensis pers. in a tropical coastal lagoon. Hydrobiologia 357:17-26

Törnblom E, Søndergaard M (1999) Seasonal dynamics of bacterial biomass and production on eelgrass Zostera marina leaves. Mar Ecol Prog Ser 179:231-240

Torréton JP, Pagès J, Talbot V (2002) Relationships between bacterioplankton and phytoplankton biomass, production and turnover rate in Tuamotu atoll lagoons. Aquat Microb Ecol 28:267-277

Tsuchiya Y, Ikenaga M, Kurniawan A, Hiraki A, Arakawa T, Kusakabe R, Morisaki H (2009) Nutrient-rich microhabitats within biofilms are synchronized with the external environment. Microbes Environ 24:43-51

Vargas CA, Martínez RA, Cuevas LA, Pavez MA and others (2007) The relative importance of microbial and classical food webs in a highly productive coastal upwelling area. Limnol Oceanogr 52:1495-1510

Warton DI, Wright IJ, Falster DS, Westoby M (2006) Bivariate line-fitting methods for allometry. Biol Rev Camb Philos Soc 81:259-291

Watnick P, Kolter R (2000) Biofilm, city of microbes. J Bacteriol 182:2675-2679

Webb JS, Givskov M, Kjelleberg S (2003) Bacterial biofilms: prokaryotic adventures in multicellularity. Curr Opin Microbiol 6:578-585

Weitere M, Bergfeld T, Rice SA, Matz C, Kjelleberg S (2005) Grazing resistance of Pseudomonas aeruginosa biofilms depends on type of protective mechanism, developmental stage and protozoan feeding mode. Environ Microbiol 7:1593-1601

Wey JK, Scherwass A, Norf H, Arndt H, Weitere M (2008) Effects of protozoan grazing within river biofilms under semi-natural conditions. Aquat Microb Ecol 52:283-296

Wu L, Blackwood CB, Leff LG (2009) Effect of single-species and mixed-species leaf leachate on bacterial communities in biofilms. Hydrobiologia 636:65-76

Ylla I, Borrego C, Romaní AM, Sabater S (2009) Availability of glucose and light modulates the structure and function of a microbial biofilm. FEMS Microbiol Ecol 69:27-42

Zhou J, Xia BC, Treves DS, Wu LY and others (2002) Spatial and resource factors influencing high microbial diversity in soil. Appl Environ Microbiol 68:326-334

Submitted: November 12, 2010; Accepted: April 19, 2011

Proofs received from author(s): July 14, 2011
Editorial responsibility: Tom Battin,

Vienna, Austria 